\title{
G20 and the Development of a New Global Governance Mechanism ${ }^{1}$
}

\author{
M. Rewizorski
}

Marek Rewizorski - PhD, Associate Professor in the Institute of Political Science, Faculty of Social Science, University of Gdańsk; 78-100 Kolobrzeg, ul. Wielkopolska 2C/15, Poland; E-mail: marek.rewizorski@ug.edu.pl

\begin{abstract}
The main objective of this article is to analyse the new global governance mechanism developed at the G20 forum by nineteen individual countries, along with the European Union (represented by the European Commission and the European Council), cooperating with international organizations (IOs) and government officials (GOs). In the subsequent sections, I argue that the new mechanistic and praxis-oriented mechanism of global governance is built on the nexus between (1) the G20 acting as a hub of multi-level cooperation and as an apex systemic risk manager; (2) IOs offering expertise on specific issue areas; and (3) GOs as sherpas, or ministers responsible for specific subjects, who are able to meet before and after commitments, and are endorsed by and influence the iteration leaders use at subsequent summits to soften difficult issues. The mechanism represents a departure from the Schumpeterian "creative destruction" process, understood in broader terms as not restricted solely to the role of entrepreneurs and innovations, but extended also towards global politics and institutions (norms, systems, and organizations). As shown in G20 communiqués and declarations, the elite global governance institutions are providing valuable input to the G20 process. A good example of the G20 and IOs' effective synergy is the relationship between the G20 and the OECD, which can be described as a "partnership of convenience." The activity of sherpas, finance ministers, central bank governors, expert groups and similar sub-summit entities are also an essential component of the global governance mechanism. They are all responsible for major preparatory work before G20 summits. In conclusion, I argue that the successful spreading of this mechanism makes it possible to achieve ambitious objectives, such as (1) crisis response and closing global governance gaps, (2) enhancing international cooperation, and (3) building a capacity for international innovation.
\end{abstract}

Key words: G20; global governance; international organizations; government officials

For citation: Rewizorski M. (2017) G20 and the development of a New Global Governance Mechanism. International Organisations Research Journal, vol. 12, no 3, pp. 32-52 (in Russian and English). DOI: 10.17323/1996-7845-2017-03-32

\section{Introduction}

Global governance, a phenomenon which has defined innumerable times within different contexts, is concerned with purposeful acts and non-tacit arrangements, and is

${ }^{1}$ The editorial board received the article in February 2017.

This article is part of the "Global Economic Governance - Actors, Areas of Influence, Interactions" research project (OPUS, 2016/23/B/HS5/00118) funded by the National Science Centre, Poland. 
neutral between activities and their outcomes. The presentations of its early versions highlighted its primary and distinctive feature of steering or governing, which departs from the rigid and hierarchical world of governments, top-down control and forced adjustments [Rosenau and Czempiel, 1992; Finkelstein, 1995]. Viewed this way, global governance has been described by the IR academia as governing without sovereign authority, steering a fragile vessel through raging seas, transcending national frontiers and doing internationally what governments do at home. Its essence has been the need for cooperation between governments and a number of non-territorial entities. As cogs in the global machinery, they all fall under the set of regularities labelled "complex interdependence" [Keohane and Nye, 2011], namely: (1) the existence of different channels of interaction (intergovernmental, transnational, non-governmental) that occur between actors of international relations; (2) the lack of a hierarchical positioning of problems in world politics, thus blurring the distinction between "low" and "high" as well as "internal" and "external" policy; and (3) the changing roles of international organizations. IOs were of minor importance after World War II but transformed into "control rooms" or "catalysts" of interdependence on a normative basis (principles, standards, procedures, shared values and collectively-achieved goals).

Actors of global governance, among which a special role is played by international organizations (e.g. the Organisation for Economic Co-operation and Development, or OECD) and global forums of cooperation bring high officials to the table - prime ministers, heads of state, as well as central bank governors or ministers (e.g. G7/8, G20). They have been arranged in a certain pattern, resembling a network of equilibrium points, set up under certain conditions in order to meet needs that emerge over time, and reflect the balance of power and interests. Over time, a change in the conditions in which international institutions operate has led to a mismatch between their resources and their declared objectives, as well as the new environment in which they operate. As a result, they may become more or less effective; if we speak metaphorically, they are more or less plugged into the grid. The emergence of a crisis may weaken them (as shown by the example of the G7), their disappearance (The Council for Mutual Economic Assistance, COMECON), put them in new roles (the OECD), or cause them to rise to unprecedented prominence (the G20), but without any guarantee that their special position will be preserved. Given this, global governance may not only denote "systems of rule at all levels of human activity - from the family to international organizations - in which the pursuit of goals through the exercise of control has transnational repercussions" [Rosenau, 1995, p. 13], but also set of mechanisms characterized by fluidity and a continual, never-ending interplay between deconstruction and reconstruction. This broader notion of governance can be conceptualized as creating the conditions for ordered rule and collective action where the outputs of governance and government may be similar but their gravity differs [Stocker, 1998; Dingwerth and Pattberg, 2006]. The dynamics of global governance, the interplay between emergence, disappearance and transformation, is a catalytic process which pushes international institutions to contribute to the effective management of collective problems. When they 
work well, institutions perform at least four valuable functions. First, they facilitate burden-sharing by governments that otherwise could not contribute to collective obligations. Second, they serve as information providers to governments. Third, they help great powers keep multiple and varied interests from getting in each other's way diplomatically. Fourth, international institutions help reinforce continuity when administrations change [Keohane and Nye, 2011]. Above all else, strong, global institutions, fully represented by the new, plurilateral summit institutions (PSIs) (namely G7/8, G20 and BRICS), are burdened in the post-Westphalian reality with the responsibility for reconstructing beyond-the-border steering mechanisms. These international cooperationoriented forums map out a new global governance mechanism, as decision-makers; both policymakers and stakeholders consider them good venues for frank discussions and sharing cross-national ideas on key policy matters [Pal, 2012, p. 16].

The main objective of this article is to analyse the new global governance mechanism developed at the G20 forum by 19 individual countries, along with the European Union (represented by the European Commission and the European Council), cooperating with international organizations (IOs) and government officials (GOs). It has been designed as a trans-border, adaptable steering mode which is subject to constant modifications. In subsequent sections, I argue that the new, mechanistic and praxisoriented mechanism of global governance is built on the nexus between (1) the G20 acting as a hub of multi-level cooperation and as apex systemic risk manager; (2) IOs offering expertise on specific issue areas; (3) GOs, as sherpas or ministers, who are responsible for specific subjects and are able to meet before and after commitments are endorsed, and who influence the iteration by which leaders at subsequent summits soften difficult issues. The mechanism represents a departure from the Schumpeterian "creative destruction" process. In conclusion, I argue that the successful spreading of this mechanism makes it possible to achieve ambitious objectives, such as (1) responding to crises and closing global governance gaps, (2) enhancing international cooperation, and (3) building capacity for international innovation.

\section{Rationale for the Emergence of a New Global Governance Mechanism and the Role of the G20}

Global governance, as noted above, can be described as a set of mechanisms characterized by fluidity and the continual, never-ending interplay between deconstruction and reconstruction. The process of the deconstruction of institutional stability in the economic and financial domains of International Relations has been particularly visible since the 1970s, and has accompanied an increasing risk of crises. The low effectiveness of governments tackling the effects of crises has become evident, and so has the deficiency in supranational governance. It took, however, several deep breakdowns of global governance mechanisms to finally recognize that the ambitions of individual countries require the development of appropriate cooperation formulae, which would go beyond what has been hitherto considered international or intergovernmental. These pursuits 
to find commonly accepted solutions accelerated after the outbreak of the 2008+ global financial crisis (GFC), that was born in the depths of the U.S. mortgage market. The six main narratives of the GFC, namely (1) a mortgage crisis, (2) a global banking crisis, (3) creative destruction, (4) a geopolitical shift, (5) a symptom of the inequality of capitalism, and (6) the opportunity to develop a green economic framework, began to resonate in the minds of policy-makers, who are always mindful of the main issues facing domestic policy and the preferences of their potential voters. Pragmatic reasoning led them to acknowledge the point of view of economists, who saw the GFC as a normal process, where destruction is followed by consolidation (or reconstruction) as an aspect of business and technology cycles [Inayatullah, 2010, pp. 91-92]. Therefore, economists and policy-makers once again called to mind the Schumpeterian "creative destruction" (restructuring) process which originally permeated the major aspects of macroeconomic performance, not only of long-term growth but also of economic fluctuations, structural adjustment and the functioning of factor markets [Schumpeter, 1942]. Managing the process of creative destruction, understood in broader terms to not simply include the role of entrepreneurs and innovations, but also that of global politics and institutions (norms, regimes, organizations), means providing appropriate responses to the tensions, crises and uncertainties generated by anarchy in the international environment. The development of a new global governance mechanism and emergence of a new institutional triad (G7/8 - G20 - BRICS) fits this pattern very well. These new (winning) structures, by taking the form of meetings (summits) of heads of state and government, and sharing the common feature of being created by a group of countries with certain common political, social and economic characteristics, became a synthesis resulting from the tension between the West and the non-West, which has increased since the end of the Cold War. The emergence of the new system was affected by such factors as: (1) growing demand for international cooperation in the context of recurring global financial and economic crises; (2) the ineffectiveness of existing triadic systems, namely the "Economic Triad" of western countries (U.S. EU - Japan) and the "Institutional Triad" of international economic organizations (IMF - World Bank - WTO), against the threats and challenges emerging in times of turbulence, accompanying the formation of a post-Cold-War international order; and (3) the rising importance and aspirations of non-western states, mostly rejecting the Washington Consensus and "western" model of global governance [Rewizorski, 2015, p. 31]. On the one hand, the formation of a new triadic, multi-centric order in the area of global governance was a result of negative factors: tensions, crises and the inefficiency of existing structures. On the other hand, positive factors related to maximizing the relative benefits of cooperation served as a catalyst for change. To put it simply, the concerned states assumed that creating systems with some degree of institutionalization, and maintaining their flexibility, is particularly important in the context of the multilevel and multidirectional nature of interactions occurring at the interstate, transnational and non-governmental levels. These structures most commonly take the form of trans-governmental regulatory networks, which due to their flexibility and non-formalized nature are easy to fit into the formula of global governance. 
It took a decade (1999-2008) for the G20 to become the apex forum tasked with tailoring an appropriate mechanism of global governance and smoothly responding to the various needs that have been raised by members of the international community. While the G7/8 and the most influential IOs became less plugged into the grid, the G20 was designed to be a club which consisted of "systemically significant" countries and the European Union, which at the very beginning assembled in order to inject stability into financial markets which were behaving wildly and almost derailed the world economy. The high point for the G20 (2008-2009), specifically two breakthrough leader summits in Washington (2008) and Pittsburgh (2009), gave this forum momentum and strengthened its image as an appropriate hub, steering a variety of institutional nodes in the G20 social network. The meeting of the leaders conducted in the heart of the United States drifted away from the G7/G8, which was often described as a "talking shop" ${ }^{21}$ [Lesage, 2007, p. 107; Debeare and Orbie, 2013, pp. 311-323], towards a G20 that leaders perceived rather as a "workshop," "steering committee" or "high table" forum that is global in composition [Cooper and Thakur, 2013, p. 16]. In this context, the Washington summit set out the key actions to mitigate the financial and economic crisis, and initiated the process of applying them and building a response to the process of globalization by creating a permanent body (G20 Leaders). As Andrew Cooper and Paola Subacchi rightfully pointed out, this G20 meeting was innovative and indispensable, showing that while the G20 is a "systemic risk manager, and a bulwark against a restrictive forms of unilateralism," it required improvements in its legitimacy and its efficiency for the world as well [Cooper and Subacchi, 2010, pp. 607-17]. Therefore it was a significant success. Heads of states, stuck together in the midst of a global depression, reaffirmed their belief that only free market principles, open trade and investment systems, and efficiently regulated financial markets can promote dynamism, creativity, and entrepreneurship, which are vital elements for accelerating economic growth, increasing employment, and eliminating poverty.

Since Washington, the task of recovery has been assigned to the G20. At the second breakthrough summit, in Pittsburgh, the G20 leaders decided to give a new status to the $\mathrm{G} 20$ and declared it the permanent, premier forum for economic governance (to the exclusion of the other 173 members of the United Nations). As one can read in point 50 of the G20 Pittsburgh Leaders' Statement, "Today, we designated the G20 as the premier forum for our international economic co-operation" [G20, 2009]. Despite arguments that the G20, by excluding 173 countries, lacks legitimacy on the "input" side, in the sense that membership of this club cannot be reversed from the formula of systemic importance [Wade and Vestergaard, 2012], the self-proclamation of G20 as the apex forum of global economic and financial governance was generally wellreceived. It is enough to say that the Chinese delegation saw the shift in geopolitical

${ }^{2}$ The G8 is frequently called a "talking shop" since its most notable output is communiqué language and rarely measurable targets or financial pledges. 
power as "conforming with the tide of history" [Sinclair, 2009]. A few months after the summit, at the World Economic Forum in Davos in January of 2010, Korean President Lee Myung-bak stated "it is time for the G20 to set the post-crisis agenda, and to build the platform that will ensure the sustained and balanced growth of the world economy in the months ahead" [Lee Myung-bak, 2010]. The reference to 2010 summitry is not accidental, as in the widespread perception of G20 scholars, after the relative successes of the summits in Toronto and Seoul, the Group of Twenty entered an on-going phase of development and maturity. This was articulated by the dynamic shaping of its agenda and eagerness to create a new global governance mechanism, tailored to the needs and abilities of its members. The Seoul summit added development to the agenda, marking the beginning of an expansion of the G20's economic and financial focus [Hajnal, 2014, p. 21]. This agenda expansion corresponds with the institutionalization of the G20, which according to Kirton [2013] crystallized into a club at the highest level, focused on deepening equality amongst its members. Since it is no longer merely preoccupied with economic issues, this global institutional structure has begun to radiate outside of Europe and North America [Martin, 2011], thus softening arguments about the deficit of the "input legitimacy" of the G20.

When subscribing to the view that the G20's elevated status has made it the hub of international economic governance, it is valuable to mention differing opinions about the G20. These are commonly formulated from the perspective of critical political economy, an application of critical theory to political economics. Dissenters focus on the processes of policy coordination and consensus formation within the Gx structures (G7, G20). In particular, Gill [1997], Bayne [1995] and Cox [1996] argued that the G7/G20 system attempts to coordinate policies among member states - often with mixed results and various disagreements and tension, while binding states and institutions into a mutually interlocking set of practices and ideologies. Cox goes on to remark that the international institutions that support global capitalism are undergoing a "transnational process of consensus formation among the official caretakers of the global economy" which is aimed at maintaining the stability and legitimacy of global capitalism [Cox, 1996, p. 301]. This economics-based process, propelled by the engine of the Washington Consensus, isolates the hubs of global governance from any social goals. However, Cox's argument regarding the role of the neoliberal and pro-market hegemony of such institutions as the G20 is difficult to defend, given the recent development of G20 outreach and engagement groups. These include Think 20 (think tanks), Labour 20, Business 20, Civil 20, Youth 20, and Women 20. The G20 outreach processes are a formal attempt by G20 leaders to engage various social sectors in G20 policymaking as well as an attempt to enhance the legitimacy and influence of the G20 and its policy proposals [Slaughter, 2015]; they are often overlooked by the critical political economy school. However, the analysis of the consequences of the G20 outreach goes far beyond the modest scope of this article and thus will not be explored here. 


\section{The Global Governance Mechanism and Its Components}

Numerous challenges face the development of G20, such as: (1) the non-democratic behaviour of some G20 participants; (2) the risk of fragmentation within this club; (3) the mounting superficial public image of the G20 as "talking shop"; (4) difficulties accommodating the interests of the great powers (such as China, the U.S., Russia), medium-sized states (such as South Korea, Australia, Canada), and emerging powers (such as India, South Africa, Brazil, Turkey, Mexico), the EU and the rest of the "systemically important" G20 actors; and (5) finally, the concerns that moving the G20 agenda far beyond its economic core will bring forth a "Christmas Tree effect," whereby it will be weighed down with too many issues. Nonetheless, the Group of Twenty's eagerness to play the role of "systemic risk manager" has not been affected. The reform, or rather transformation of the group from an anti-crisis committee to a hub of multi-level institutionalization is noticeable. To secure this process, the G20 strives for close cooperation with international organizations (IOs) offering expertise on specific issue areas, and uses government coordinating measures (government officials, GOs) as sherpas, or ministers responsible for specific subjects, which meet before and after commitments are endorsed (Fig. 1).

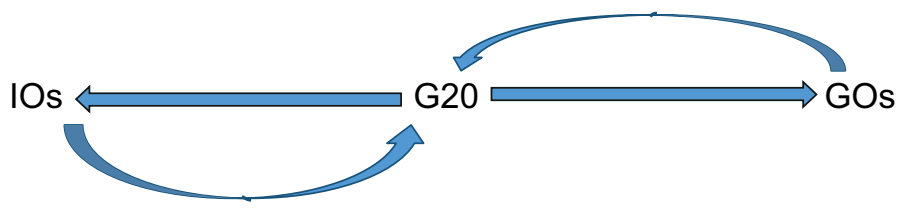

Fig. 1. Societal Structure of the Global Governance Mechanism

This triple actor approach (G20 - IOs - GOs) influences the iteration by which leaders at subsequent summits soften difficult issues. Combined, they create a societal structure which gives substance to the global governance mechanism overseen by the G20.

\section{International Organizations and the G20}

A good example of the effective synergy between the G20 and IOs is the relationship between the G20 and the OECD, which can be described as a "partnership of convenience." The historically-forged partnership of convenience between the G20 and the OECD is growing in importance. It relies on a specific exchange: the OECD offers experience and knowledge, whereas the G20 provides a high level of political commitment to the OECD's agenda, thereby increasing the relevance of the OECD within the architecture of global economic governance. This cooperation is underpinned by the economic dependency of the OECD on G20 members (Fig. 2).

These "family bonds" are not surprising, as the G20 mandate, which encompasses the coordination of policies and makes globalization a more harmonious and sustainable process, meets the analogous mandate of the OECD [Ramos, 2011, p. 334]. 


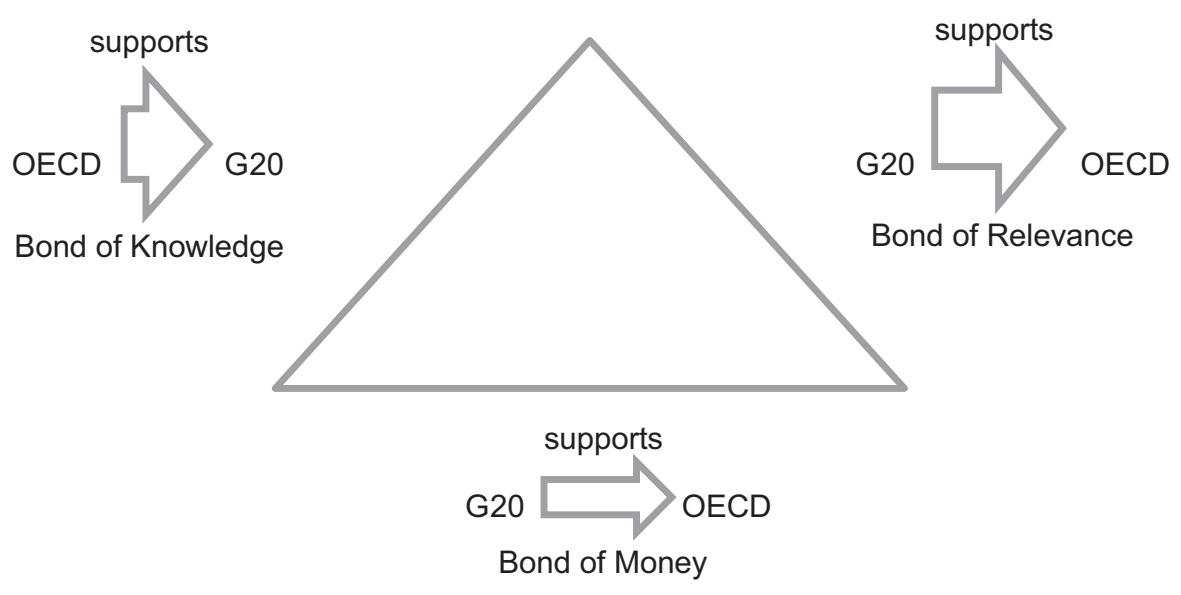

Fig. 2. OECD - G20 Triangle of Cooperation

Source: [OECD, 2016; Pal, 2012; Ramos, 2011].

The first bond between the OECD and the G20 is expressed in the group of twenty striving for the development of highly professional working groups, and thus looking for an expert community with the ability to provide counsel and administrative support in this area. It is worth noting that with the unfolding of the global agenda after the 2008 Washington summit, the G20 has become a hub of multiple epistemic communities, working groups and technical committees. During the summit in Toronto (2010) the G20 agreed to establish a Working Group on Development and mandate that it elaborate a development agenda and multi-year action plans to be adopted at the Seoul summit. This "body," co-chaired by South Korea and South Africa, was adopted by the G20 leaders as part of the so called "Seoul Development Consensus for Shared Growth" and the "Multi-Year Action Plan," which had been developed for the purpose of narrowing the development gap between poor and rich countries, and also reducing poverty in developing countries. Building on the G20 agreement reached in Toronto, the G20 leaders agreed to establish a G20 Working Group on Anti-Corruption, co-chaired by Indonesia and the United Kingdom [Rewizorski, 2014, p. 104]. These examples showcase the input of the OECD, which as an international organization supports the G20 with specialist information, policy advice and technical analysis. The OECD contributes to all stages of preparation for G20 summits. At the highest political level, the OECD Secretary General participates in the Leaders' summit. The Global Governance and Sherpa Unit, under the supervision of the OECD Chief of Staff and Sherpa to the G20, coordinates all the contributions to the G20. These take various forms, depending on the deliverables and tasks assigned by the G20 members.

The G20 - OECD relationship is not unidirectional. The OECD, as an international organization, also benefits from the G20 process, which helps to coordinate its work, provide leverage to it, and where necessary injects the political momentum needed to break deadlocks. Hence the second bond between these two institutions is expressed in the aforementioned high level of political commitment to the OECD's 
agenda by the G20, thereby increasing the relevance of the OECD within the architecture of global economic governance. As shown in G20 communiqués and declarations, the OECD is placed amongst the elite global governance institutions, alongside the UN, IMF, World Bank Group, WTO, ILO, FSB, FATF and BIS, "providing valuable inputs to the G20 process" [G20, 2015]. A quantitative analysis of the Antalya communique found that the UN (including UNCTAD and UNFCCC) was referred to 10 times, IMF -12 , World Bank -3 , the OECD - 26, WTO - 4, ILO - 2, FSB - 11, FATF -3 , and BIS -1 (Figure 3).

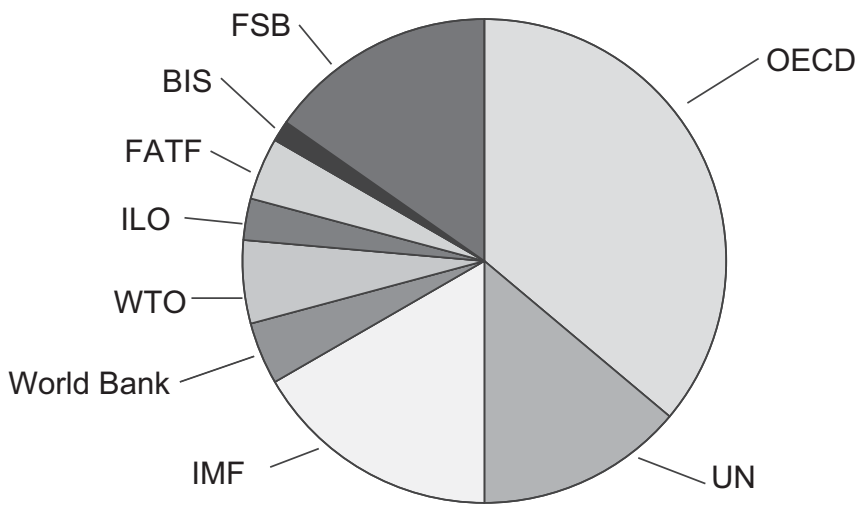

Fig. 3. Relevance of Selected IOs within the Global Economic Governance Architecture in the Antalya G20 Leaders' Communiqué [2015]

Source: [G20, 2015].

This dominant position was also occupied by the OECD in the Antalya G20 summit communiqué annex, consisting of agreed-upon documents, ministerial statements, working group documents, supporting documents and issues for further action. This organization has co-produced a series of documents with the G20 in pivotal areas, such as: (1) G20/OECD Report on G20 Investment Strategies; (2) G20/OECD Principles of Corporate Governance; (3) G20/OECD High-Level Principles on SME Financing; (4) Quantifying the Implementation of G20 Members' Growth Strategies (IMF - OECD Note); (5) OECD/INFE Core Competencies Framework on Financial Literacy for Youth; (6) OECD/INFE Policy Handbook on the Implementation of National Strategies for Financial Education; (7) Financial Education for Migrants and Their Families: OECD/INFE Policy Analysis and Practical Tools; (8) OECD/ INFE Progress Report on Financial Education for MSMEs and Potential Entrepreneurs; (9) Toolkit to Enhance Access to Adaptation Finance for Developing Countries that are Vulnerable to the Adverse Effects of Climate Change Including LIDCs, Small Island Developing States and African States (OECD in Collaboration with the Global Environment Facility); (10) Climate Funds Inventory; (11) OECD Secretary-General Report to the G20 Leaders; (12) Effective Approaches to Support Implementation of the G20/OECD High-Level Principles on Long Term Financing by Institutional 
Investors; and (13) OECD Secretary-General Report to G20 Finance Ministers with Its Annexes ("Reports on Possible Tougher Incentives for the Countries that Fail to Comply with the Global Forum Standards on Exchange of Information on Request" and "SMEs and Taxation") [G20, 2015, pp. 8-11].

The third strong incentive for growing cooperation stems from the dependency of the OECD on G20 members for its budgets (see Table 1).

Table 1. G20 Member Countries’ Percentage Shares in the OECD Budget Contribution (2015)

\begin{tabular}{|l|c|}
\hline \multicolumn{1}{|c|}{$\begin{array}{c}\text { The G20 Participants and OECD Member } \\
\text { Countries from the EU }\end{array}$} & $\begin{array}{c}\text { Percentage Share in the OECD Budget } \\
\text { (EUR 383 min = 100\%) }\end{array}$ \\
\hline United States & 21.07 \\
\hline Japan & 11.92 \\
\hline Germany & 7.57 \\
\hline France & 5.53 \\
\hline United Kingdom & 5.21 \\
\hline Italy & 4.35 \\
\hline Canada & 3.87 \\
\hline Australia & 3.28 \\
\hline South Korea & 2.82 \\
\hline Mexico & 2.71 \\
\hline Turkey & 1.79 \\
\hline $\begin{array}{l}\text { The rest of the European OECD member countries } \\
\text { participating in the EU* }\end{array}$ & 21.69 \\
\hline
\end{tabular}

Note: * OECD members participating in the EU apart from the E4 (Germany, France, United Kingdom and Italy) include: Spain (3.11\%), Netherlands (2.18\%), Belgium (1.56\%), Sweden (1.55\%), Estonia (1.43\%), Poland (1.43\%), Slovenia (1.43\%), Austria (1.36\%), Denmark (1.21\%), Finland (1.08\%), Greece (1.06\%), Portugal (0.99\%), Czech Republic (0.96\%), Ireland (0.95\%), Hungary $(0.81 \%)$, Slovak Republic $(0.58 \%)$.

Source: [OECD, 2016].

The G20 members' financial contributions to the OECD budget (EUR $383 \mathrm{mln}$ ), including that of the E4 countries (Germany, France, United Kingdom, Italy), accounted for $70.12 \%$ in 2015 . However, if contributions to the OECD budget from nonE4 European OECD member states participating in the EU (21.69\%) are included, it amounts to $91.81 \%$ (EUR $351.6 \mathrm{mln}$ ). This high financial dependence on G20 countries (even indirectly represented in this forum) suggests that OECD support is offered according to a "pay as you go" model, which explains why its attention is mainly focused on Europe.

The strong relationship between the OECD and G20 showcased above leads to the conclusion that international organizations with a transregional-reach (such as the 
IMF, OECD, FSB, WB, FATF, BIS, G24, G77 and ASEAN+3), serving often as the Groups' technical assistance providers, occupy a prominent position in "the G20 galaxy." It is not only the participation of the IOs of member-states in the G20 which stabilize the galaxy (or network), but also the rapid institutionalization of the G20, that clears the way for plurilateral informal institutions to win out over the old formal multilateral organizations. This trend has been highlighted in the literature by Kirton, Larionova, and Savona [2010], who noted that this happened in order to assure that the Gx process provided IOs the resources and reforms it could not secure from states on its own. The Gx process has also created new international organizations, such as the FSB, that are separate from the IMF and born in a plurilateral form to manage the completion of designated tasks. While such bodies as the OECD and IMF have begun to play the role of helpers in the delivery of tasks shortlisted in the G20 (also G7), PSI focused on providing a high level of political commitment to the IOs agenda, thereby increasing their relevance within the architecture of global economic governance.

\section{The G20 and Government Officials}

According to the classical view, persons acting on behalf of states in international bodies are classified into three groups: (1) leading figures exercising political authority, normally heads of state, as well as heads of government and foreign ministers, together with those associated with the process of government (for example, a parliamentary assembly); (2) ambassadors and others sent abroad in connection with the bilateral exchange of embassies; and (3) the dispatch of a special mission [Hardy, 1969]. While in the first group the political figures mentioned may, within the bounds of the constitution, commit a state to a range of obligations or negotiate any agreement, the second group has to act under instruction but possesses a general right of representation, namely the right to represent the state in all aspects of its foreign relations. Special missions, on the other hand, though equally official, are entitled only to perform specific tasks as agreed upon between two states, and do not have broad authority in all spheres.

The G20, as a club of international cooperation, departs from the rigid and archetypical form of diplomatic activities in the international realm. Depending on the format of the forum (G20 Finance or G20 Leaders), the group takes advantage of the activity of finance ministers, central bank governors, ministerial forums as well as expert groups and similar sub-summit entities. Major preparatory work that precedes G20 summits is entrusted to sherpas and the personal representatives of the leaders. ${ }^{32}$ Usually, personal representatives are appointed for a period which lasts more than 12 months, as the tasks delegated to them are huge. They include holding consultations before upcoming summits, negotiating agenda items, the presentation of positions adopted by individual countries, reaching agreements on most important issues, as well

${ }^{3}$ The term "sherpa" originates from the Tibetan language and means sher - east $+p a-$ people. The name comes from the tribe of Sherpa people of Nepal, from among whom helpers and porters were recruited for Himalayan expeditions. With time, the word started to be used to describe all kinds of helpers. 
as providing assistance and advice to the summit's host country. The preparatory process also includes sherpa consultations with non-government stakeholders such as the business sector, think-tanks and civil society groups. Some G8 members of the G20 use the same person as sherpa for both G8 and G20. The sherpas are assisted by deputy finance ministers ("finance deputies").

Table 2. Sherpa and Ministerial Meetings Schedule Leading up to the G20 St. Petersburg Summit

\begin{tabular}{|c|c|}
\hline Date of Meeting/Summit & Level of Meeting/Summit \\
\hline 5-6 September 2013 & G20 Leaders' Summit \\
\hline 5-6 September 2013 & G20 Sherpas and Finance Deputies \\
\hline 5-6 September 2013 & G20 Finance Deputies \\
\hline 25-26 July 2013 & G20 Sherpas \\
\hline 19-20 July 2013 & G20 Finance Ministers and Central Bank Governors \\
\hline 18-19 July 2013 & Joint G20 Finance and Labour Ministers \\
\hline 18 July 2013 & G20 Labour Ministers \\
\hline 18 July 2013 & Labour Ministers With Social Partners \\
\hline 17 July 2013 & Task Force on Employment \\
\hline 17 July 2013 & Social Partners (B20 and L20) \\
\hline 9-10 July 2013 & Energy Sustainability Working Group \\
\hline 8-10 July 2013 & G20 Development Working Group \\
\hline 3-4 July 2013 & Framework for Strong, Sustainable and Balanced Growth Working Group \\
\hline 20-21 June 2013 & Business 20 Summit (B20) \\
\hline 18-21 June 2013 & Youth 20 Summit (Y20) \\
\hline 13-14 June 2013 & Civil 20 Summit (C20) \\
\hline $6-7$ June 2013 & G20 Finance Ministers and Central Bank Governors’ Deputies \\
\hline 6-7 June 2013 & Anti-Corruption Working Group \\
\hline 5 June 2013 & Task Force on Employment and G20 Finance Deputies \\
\hline 3-4 June 2013 & Task Force on Employment \\
\hline 11-12 Мay 2013 & G20 Sherpas, St. Petersburg \\
\hline 18-19 April 2013 & G20 Finance Ministers and Central Bank Governors, Washington DC \\
\hline 15-16 February 2013 & G20 Finance Ministers and Central Bank Governors \\
\hline 4-5 November 2012 & G20 Finance Ministers and Central Bank Governors \\
\hline $29-30$ October 2012 & G20 Sherpas \\
\hline 4-5 October 2012 & G20 Development Working Group \\
\hline $4-5$ October 2012 & Agricultural Market Information System \\
\hline $1-2$ October 2012 & G20 Task Force on Employment \\
\hline $24-25$ September 2012 & G20 Finance Ministers and Central Bank Governors, Mexico City \\
\hline
\end{tabular}

Source: [Rewizorski, 2014, p. 149]. 
Sherpas, with the gradual broadening of the G20 agenda, are amassing more competences, which translates into fulfilling more duties. They usually meet 3-4 times a year and are generally well prepared to carry out tasks, as they usually hold important positions in governments. Table 3 outlines the G20 sherpas' government positions.

Table 3. G20 Sherpas in January 2014

\begin{tabular}{|c|c|}
\hline Country & Sherpa/Position \\
\hline Argentina & Cecilia Nahón, Ambassador of Argentina to the United States \\
\hline Australia & $\begin{array}{l}\text { David Gruen, Deputy Secretary, Department of the Prime Minister and Cabinet } \\
(\text { PM\&C) }\end{array}$ \\
\hline Brazil & $\begin{array}{l}\text { Enio Cordeiro Ambassador, Undersecretary for Economy and Finance, Ministry of } \\
\text { Foreign Relations }\end{array}$ \\
\hline Canada & $\begin{array}{l}\text { Vincent Rigby, G20 Sherpa, Assistant Deputy Minister and G7 Foreign Affairs Sous- } \\
\text { Sherpa }\end{array}$ \\
\hline China & Baodong Li, Chinese G20 Sherpa and Vice Foreign Minister \\
\hline European Union & $\begin{array}{l}\text { Richard Szostak, G20 Sherpa, Diplomatic Advisor of President Juncker, European } \\
\text { Commission }\end{array}$ \\
\hline France & Laurence Boone, G20 Sherpa of the French President \\
\hline Germany & $\begin{array}{l}\text { Lars-Hendrik Röller, Economic and Financial Policy Advisor to the Federal } \\
\text { Chancellor, G7- and G20-Sherpa }\end{array}$ \\
\hline India & Suresh Prabhakar Prabhu, Minister for Railways and G20 Sherpa, Government of India \\
\hline Indonesia & $\begin{array}{l}\text { Rizal Affandi Lukman, Deputy Minister for International Economic Cooperation, } \\
\text { Coordinating Ministry for Economic Affairs of the Republic of Indonesia }\end{array}$ \\
\hline Italy & $\begin{array}{l}\text { Armando Varricchio, Ambassador, Diplomatic Advisor to the Prime Minister and G7/ } \\
\text { G20 Sherpa Prime Minister's Office }\end{array}$ \\
\hline Japan & Yasumasa Nagamine, Deputy Minister, Ministry of Foreign Affairs \\
\hline Mexico & $\begin{array}{l}\text { Carlos de Icaza, Deputy Minister of Foreign Affairs \& G20 Sherpa, Ministry of Foreign } \\
\text { Affairs of Mexico }\end{array}$ \\
\hline Russia & $\begin{array}{l}\text { Svetlana Lukash, G20 Sherpa, Deputy Chief of Presidential Experts' Directorate, } \\
\text { Executive Office of the President }\end{array}$ \\
\hline Saudi Arabia & Hamad Albazai, Vice Minister of Finance \\
\hline South Africa & $\begin{array}{l}\text { Ambassador Jerry Matjila, Director-General: Department of International Relations } \\
\text { and Cooperation }\end{array}$ \\
\hline South Korea & Hye Min LEE, Ambassador for International Economic Affairs, G20 Sherpa \\
\hline Turkey & $\begin{array}{l}\text { Ayşe Sinirlioğlu, Ambassador, Deputy Undersecretary for Economic Affairs and G20 } \\
\text { Sherpa, MFA }\end{array}$ \\
\hline United Kingdom & Tom Scholar, Second Permanent Secretary, Prime Minister's Europe Advisor \\
\hline $\begin{array}{l}\text { United States of } \\
\text { America }\end{array}$ & $\begin{array}{l}\text { Caroline Atkinson, Deputy Assistant to the President and Deputy National Security } \\
\text { Advisor for International Economic Affairs }\end{array}$ \\
\hline
\end{tabular}

Source: G20 Sherpa list. Available at: http://www.g20civil.com/sherpateam/sherpa-list.php (accessed 1 February 2017). 
Noticeably the G20 sherpas are recruited mostly from the economic and financial sector. They cooperate with ministers dealing with the sector and central bank governors, who are supported by numerous expert and working groups. As a rule, these groups are co-chaired by one advanced and one emerging country member of the G20 [Hajnal, 2014, p. 41]. The German presidency of the G20 plans to organize six ministerial meetings, including a meeting of finance ministers and central bank governors. In the run-up to the G20 summit, the German host established a time and place for the specialized meetings (Table 4)

Table 4. Overview of the G20 Specialized Ministers' Meetings in 2017

\begin{tabular}{|l|l|l|}
\hline \multicolumn{1}{|c|}{ Ministry } & \multicolumn{1}{c|}{ Venue } & \multicolumn{1}{c|}{ Date } \\
\hline Meeting of G20 Agriculture Ministers & Berlin & 22 January 2017 \\
\hline Meeting of G20 Foreign Ministers & Bonn & 16-17 February 2017 \\
\hline $\begin{array}{l}\text { Meeting of G20 Finance Ministers and Central } \\
\text { Bank Governors }\end{array}$ & Baden-Baden & 17-18 March 2017 \\
\hline $\begin{array}{l}\text { Meeting of G20 Ministers in Charge } \\
\text { of Digitalization }\end{array}$ & Düsseldorf & 6-7 April 2017 \\
\hline Meeting of G20 Labour Ministers & Bad Neuenahr & 18-19 May 2017 \\
\hline Meeting of G20 Health Ministers & Berlin & 19-20 May 2017 \\
\hline
\end{tabular}

Source: [G20, 2017].

The meeting of G20 agriculture ministers in Berlin, where participants agreed on the G20 Agriculture Ministers' Declaration and Action Plan, focused on the sustainable use of water, digitalization, and committed members to produce a roadmap for ending the use of antibiotics in agriculture to promote growth [G20, 2017]. An analysis of the declaration demonstrates the presence of the mechanism of global governance in the sector that is based on the G20-IOs-GOs nexus. The G20 Ministers of Agriculture $^{4}$ highlighted the support of G20 economies for the 2030 Agenda for Sustainable Development (administered by the UN), ${ }^{5}$ the Paris Agreement on climate change (administered by the UNFCCC), combating antimicrobial resistance and contributing to a "one health" approach by using OECD, WHO and FAO expertise, finally developing the Agricultural Market Information System (AMIS) launched in 2011 by the G20 agriculture ministers. ${ }^{6}$ The short declaration abounded in invitations to use the

${ }^{4}$ G20 agriculture ministers met on 22-23 June 2011 in Paris to discuss the volatility of agricultural commodity prices.

${ }^{5}$ Particularly in reference to SDG 6, which aims, inter alia, at substantially increasing water-use efficiency, ensuring sustainable withdrawals, improving water quality and implementing integrated water-resource management.

${ }^{6}$ The Agricultural Market Information System (AMIS) was established in order to "encourage major players in the agri-food markets to share data, to enhance existing information systems, to promote a greater shared understanding of food price developments, and further policy dialogue and co-operation" [G20, 2011, p. 7]. AMIS was set as an early warning system which indicates potential food crises by monitoring prices, trade, 
expertise of various working groups operating in agricultural, environmental or health domains, such as the Group on Earth Observations Global Agricultural Monitoring (GEOGLAM) initiative, which joined AMIS in June 2016.

\section{Conclusions}

The new global governance mechanism is based on a triple actor approach, where: (1) the G20 acts as a hub of multi-level cooperation and apex systemic risk manager; (2) IOs offer expertise on specific issue areas; (3) GOs, as sherpas, or ministers influence the iteration by which leaders at subsequent summits soften difficult issues. This new mechanistic and praxis-oriented system of global governance has been built to achieve such objectives as: (1) responding to crises and closing global governance gaps; (2) enhancing international cooperation; and (3) building capacity for international innovation. As for reaching the first objective, the G20, as helmsman, is accountable for preparing the mechanisms for responding to crises and closing global governance gaps. It partly explains why subsequent summits have embraced so many new issues. Suffice to say that, apart from the initial G20 summit, where the number of commitments did not exceed 100, at subsequent summits their number increased, averaging between 150 and 300. Despite the G20 focus being fixed on core issues, such as macroeconomic policy, financial regulation, trade and investment and reforming global financial institutions, it is gradually broadening its agenda, which is sometimes criticized for leading to a "Christmas Tree effect." Indeed, the OECD report [2016] Contributions to the G20 lists 16 issue areas which are debated at every summit and constantly appear in communiqués, declarations and action plans. The can be grouped into:

- global economic governance: (1) Framework for Strong, Sustainable and Balanced Growth; (2) SMEs and Corporate Governance; (3) Financial Education and Financial Consumer Protection, (4) Taxation; (5) International Financial Architecture \& Long-term Investment; (6) Investment and Trade;

- global sustainable development governance: (7) Disaster Risk Management; (8) Energy Architecture, Energy Efficiency and Fossil Fuels; (9) Green Growth; (10) Green Finance; (11) Climate Finance; (12) Food Security and Agriculture,

(13) Development; (14) Employment and Social Policies;

- global security governance: (15) Anti-corruption; (16) Co-operation among International Organizations

The list is still open, especially as attention at G20 summits is often hijacked by current political issues, such as Russian activity in Eastern Ukraine, international terrorism, Brexit or the migrant crisis in Europe, to name only a few. Responding to these crises, and closing global governance gaps, as the objective of the new Global Gover-

output and inventory of such basic commodities as wheat, rice, soya bean, and maize [AMIS, 2014]. It provides its participants (G20 members, Spain and seven major producing, consuming and exporting countries of commodities covered by AMIS - Egypt, Kazakhstan, Nigeria, the Philippines, Thailand, Ukraine, and Vietnam) with complementary analysis of selected agricultural products in areas of supply and demand, crops, international prices, policy developments and market access. 
nance Mechanism, on the one hand spurs the creation of an anti-crisis, firewall facility, with more equal participation and the empowerment of non-western powers, but at the same time is hamstrung by political volatility and multisided influences. The examples of the reform of Bretton Woods institutions and introduction of a global financial transaction tax stand out. In the first case, despite the United States' fierce opposition, the reform, approved in December 2010 by the IMF board of governors, was revived in 2015 after the United States Congress allowed the reform package to take effect in January 2016. Also, on 1 October 2016 the renminbi was added to the IMF's basket of Special Drawing Rights (SDR). Therefore, the G20 took probably the last chance to successfully contribute to the development of international economic governance, and this is a positive example where the closing of governance gaps was in fact possible. In the second case, the idea of "civilizing" the global financial sector and shifting the burden of emergency bailouts away from taxpayers by introducing the Financial Transaction Tax, despite being put on the table by the G20 in 2008, proved to be almost unworkable. Again, the stumbling block was the wild opposition flowing from the United States, influenced by powerful lobbies of investors, bankers, hedge funds and CRIs. Despite the tax proposal failures at the G20, this is an idea which will probably be bouncing back, as shown by the example of German Finance Minister Wolfgang Schaeuble's proposal in mid-2016 to place a financial transactions tax (FTT) on the G20's agenda. Surely, the catalyst which prompted the G20 to revive the idea was European fears of Brexit (which is a political issue) combined with failed FTT Plans among all 28 European Union members.

The second and third objectives of the new global governance mechanism are enhancing international cooperation and building capacity for international innovation. In achieving its second objective, the G20 benefits from the support of IOs. In official documents endorsed at G20 leaders' summits, there are references to supporting the ongoing work; recommendations and initiatives on a given issue area led by an external organization. As shown by G20 communiqués and declarations, elite global governance institutions are deployed within a certain, replicating pattern. According to the G20 Research Group methodology, the referencing of IOs can be described as the "development of global governance." However, reaching this objective using the global governance mechanism has its weak spots. The OECD, as well as other global institutions such as the IEA or the IMF, is still perceived by China and other BRICS economies as a western bulwark not reflective of the current economic multipolarity. Given the narrow base of their membership, or relatively small voting power of their nonwestern members, the effectiveness of these prominent IOs is limited. Finally, the third objective of the New Global Governance Mechanism has been to build capacity for international innovation at various levels. A good example here may be the G20 Digital Economy Development and Cooperation Initiative, which was agreed upon during the Hangzhou summit. The goal here is to ensure that an additional 1.5 billion people are connected and have meaningful access to the internet by 2020 through expanded and affordable broadband access. This goal is in line with "Broadband Europe," a European Commission strategy adopted in September 2016 and focused on providing every 
European with personal Internet access at speeds of up to 30 Mbps and half of households with a 100 Mbps connection by 2020. It is obvious that meeting this ambitious digital agenda will not be possible without the active involvement of GOs.

The above-mentioned aspects of the global governance mechanism are interconnected. The three-actor cooperation approach aims at building a mechanism which is centred on achieving three main objectives. The stability of the whole mechanism is, however, dependent on (1) openness to collectively solving problems; (2) improving the cooperation of the G20 with other PSIs (G7/8 and BRICS) and the UN as a political centre of global governance; (3) enhancing legitimacy and efficiency, through maximizing compliance with G20 commitments and closer cooperation with civil society organizations; and, finally, (4) the resilience of the G20 mechanism necessitates the further inclusion of China and other developing countries into global decision-making processes. The global governance mechanism outlined here is still in an early stage of its development.

Despite its value in understanding the effectiveness of the G20 as an apex forum of global governance, the triple actor approach has its limitations. It may be well used in researching the bonds between plurilateral summit institutions (G7, G20, BRICS) and international organizations with a transregional reach, which often serve as the PSI's technical assistance providers, and thus occupy a prominent position in their networks or galaxies. However, as a research tool, it seems to be too narrow to analyse the multidimensional relationships between the G20 and the UN, which are subject to fluctuation and turbulence. Today the debate in this domain is function of divergent "schools" which, despite making useful contributions, are more normative and prescriptive than they are analytical or empirical. This short review takes up the task of a comprehensive, contemporary and systematic study, ushering in a more analytical view on global governance and its architecture.

\section{References}

AMIS (2014) Crop Monitor. Available at: http://www.amis-outlook.org/amis-monitoring/crop-monitor/ overview/en/ (accessed 10 February 2017).

Bayne N. (1995) The G7 Summit and the Reform of Global Institutions. Government and Opposition, vol. 30 , no 4, pp. 492-509.

Cooper A.F., Subacchi P. (2010) Overview. International Affairs, vol. 86, no 3.

Cooper A.F., Thakur R. (2013) The Group of Twenty (G20). New York: Routledge.

Cox R. (1996) Approaches to World Order. Cambridge: Cambridge University Press.

Debaere P., Orbie J. (2013) The European Union in the Gx System. Routledge Handbook on the European Union and International Institutions: Performance, Policy, Power (K.E. Jørgensen, K.V. Laatikainen (eds)). London: Routledge.

Dingwerth K., Pattberg P. (2006) Global Governance as a Perspective on World Politics. Global Governance, vol. 12, no 2.

Finkelstein L. (1995) What is Global Governance. Global Governance, vol. 1, no 1.

G20 (2009) G20 Leaders' Statement: The Pittsburgh Summit, Pittsburgh, 25 November. Available at: http:// www.g20.utoronto.ca/2009/2009communique0925.html (accessed 10 February 2017). 
G20 (2011) Ministerial Declaration: Action Plan on Food Price and Volatility and Agriculture. Meeting of G20 Agriculture Ministers, Paris, 22 and 23 June.

G20 (2015) G20 Leaders' Communiqué, Antalya Summit, 15-16 November.

G20 (2017) Ministers Meetings and Workings Groups. Available at: https://www.g20.org/Webs/G20/ EN/G20/meeting_ministers/meetings_ministers_node.html (accessed 10 February 2017).

Gill S. (1997) Global Structural Change and Multilateralism. Globalisation, Democratisation and Multilateralism (S. Gill (ed.)). Basingstoke: Macmillan.

Hajnal P.I. (2014) The G20. Evolution, Interrelationships, Documentation. Routledge.

Hardy M. (1969) The Diplomatic Activities of International Organizations: The United Nations and the European Communities Contrasted. Revue Beige de Droit International, no 2.

Inayatullah S. (2010) Deconstructing and Reconstructing the Global Financial Crisis. Experiments with peace: celebrating peace on Johan Galtung's 80th birthday (J. Johansen, J. Y. Jones (eds)). Cape Town: Pambazuka Press.

Keohane R., Nye Jr J. (2011) Power and Independence. World Politics in Transition. Fourth Edition. Longman, New York.

Kirton J., Larionova M., Savona P. (eds) (2010) Making Global Economic Governance Effective: Hard and Soft Law Institutions in a Crowded World. Farnham, U.K.: Ashgate.

Kirton J. (2011) The Group of Twenty. Handbook of Transnational Governance Innovation (T. Hale, D. Held (eds)). London: Polity Press.

Kirton J. (2013) G20 Governance for a Globalized World. Farnham: Ashgate.

Lesage D. (2007) Is the World Imaginable Without the G8? Internationale Politik und Gesellschaft, vol. 4. Available at: http://www.fes.de/ipg/2007/4/09_Lesage_US.pdf (accessed 10 February 2017).

Martin P. (2011) The G20: From Global Crisis Responder to Global Steering Committee. Global Leadership in Transition: Making the G20 More Effective and Responsive (C.I. Bradford, W.H. Lim (eds)). Washington, DC: Brookings Institution Press with Korean Development Institute.

Myung-bak L. (2010) Seoul G20 Summit: Priorities and Challenges. Davos, Switzerland, 28 January.

OECD (2016) Member Countries' Budget Contributions, Budget. Available at: www.oecd.org/about/budget/member-countries-budget-contributions.htm (accessed 10 February 2017).

Pal L.A. (2012) Frontiers of Governance: The OECD and Global Public Management Reform. Basingstoke: Palgrave Macmillan.

Ramos G.I. (2011) The OECD in the G20: A Natural Partner in Global Governance. The George Washington International Law Review, vol. 43, no 2, pp. 325-343.

Rewizorski M. (2014) From Washington to St. Petersburg. Development of the G20 as a New Centre of Global Governance. Berlin: Logos Verlag.

Rosenau J., Czempiel E-O. (eds) (1992) Governance Without Government. Order and Change in World Politics. Cambridge University Press, Cambridge.

Rosenau J.N. (1995) Governance in the Twenty-first Century. Global Governance, vol. 1, no 1.

Schumpeter J. (1942) Capitalism, Socialism, and Democracy. New York: Harper \& Bros.

Sinclair J. (2009) The New Global Governance: Time for a Great Leap Forward. Options Poliques. November.

Slaughter S. (2015) Building G20 Outreach: The Role of Transnational Policy Networks in Sustaining Effective and Legitimate Summitry. Global Summitry, vol. 1, iss. 2, pp. 171-186.

Stoker G. (1998) Governance as Theory: Five Propositions. International Social Science Journal, vol. 50, iss. 155 .

Wade R., Vestergaard J. (2012) The G20 has Served its Purpose and Should be Replaced. Journal of Globalization and Development, vol. 2, no 2. 


\section{«Группа двадцати» и развитие нового механизма глобального управления ${ }^{1,2}$}

\section{М. Ревизорский}

Ревизорский Марек - доктор, доцент Института политологии факультета социологии Гданьского университета; 78-100 Kolobrzeg, ul. Wielkopolska 2C/15, Poland; E-mail: marek.rewizorski@ug.edu.pl

Основная цель данной статьи - проанализировать новый механизм глобального управления, выработанный в рамках форума «Группы двадиати» девятнадиатью наиболее развитыми экономиками мира, а также ЕС в лице Европейской комиссии и Европейского совета при сотрудничестве с международными организациями (МО) и представителями органов власти.

Автор статьи отказывается от теории «созидательного разрушения» Шумпетера и полагает, что новый, ориентированный на практические результаты механизм глобального управления создается на основании соединения между (1) «Группой двадцати», действующей как центр многоуровневого сотрудничества и вершины управления системными рисками; (2) международными организациями, предлагающими свою экспертизу по конкретным тематическим сферам; и (3) представителями органов власти (шерпы или министры, ответственные за конкретные вопросы, которые встречаются, чтобы обсудить подготовку и исполнение принятых обязательств, и обеспечивают выработку решений, одобряемых лидерами на саммитах для решения сложных вопросов.

В заключительной части статьи автор отмечает, что успешное распространение этого механизма позволило достичь амбициозных результатов, таких как (1) создание механизма смягчения последствий экономического кризиса и устранения лакун в системе глобального управления; (2) наращивание международного сотрудничества и (3) формирование потенциала для распространения инновационных подходов.

Ключевые слова: «Группа двадцати»; глобальное управление; международные организации; представители органов власти

Для цитирования: Ревизорский М. «Группа двадцати» и развитие нового механизма глобального управления // Вестник международных организаций. 2017. T. 12. № 3. C. 32-52. DOI: 10.17323/1996-7845-2017-03-32

\section{Литература}

AMIS (2014) Crop Monitor. Режим доступа: http://www.amis-outlook.org/amis-monitoring/crop-monitor/ overview/en/ (дата обращения: 10.02.2017).

Bayne N. (1995) The G7 Summit and the Reform of Global Institutions // Government and Opposition. Vol. 30. No. 4. P. 492-509.

Cooper A.F., Subacchi P. (2010) Overview // International Affairs. Vol. 86. No. 3.

Cooper A.F., Thakur R. (2013) The Group of Twenty (G20). N.Y.: Routledge.

Cox R. (1996) Approaches to World Order. Cambridge: Cambridge University Press.

${ }^{1}$ Статья поступила в редакцию в феврале 2017 г. Перевод выполнен Е.А. Сафонкиной, научным сотрудником Центра исследований международных институтов Российской академии народного хозяйства и государственной службы при Президенте РФ (РАНХиГС).

${ }^{2}$ Статья подготовлена в рамках проекта «Глобальное экономическое управление - акторы, сферы влияния, взаимодействие» (OPUS, 2016/23/B/HS5/00118), финансируемого Национальным научным центром Польши. 
Debaere P., Orbie J. (2013) The European Union in the Gx System // Routledge Handbook on the European Union and International Institutions: Performance, Policy, Power / K.E. Jørgensen, K.V. Laatikainen (eds). L.: Routledge.

Dingwerth K., Pattberg P. (2006) Global Governance as a Perspective on World Politics // Global Governance. Vol. 12. No. 2.

Finkelstein L. (1995) What is Global Governance // Global Governance. Vol. 1. No. 1.

G20 (2009) G20 Leaders' Statement: The Pittsburgh Summit, Pittsburgh. 25 November. Режим доступа: http://www.g20.utoronto.ca/2009/2009communique0925.html (дата обращения: 10.02.2017).

G20 (2011) Ministerial Declaration: Action Plan on Food Price and Volatility and Agriculture. Meeting of G20 Agriculture Ministers. Paris, 22 and 23 June.

G20 (2015) G20 Leaders' Communiqué. Antalya Summit, 15-16 November.

G20 (2017) Ministers Meetings and Workings Groups. Режим доступа: https://www.g20.org/Webs/G20/EN/ G20/meeting_ministers/meetings_ministers_node.html (дата обращения: 10.02.2017).

Gill S. (1997) Global Structural Change and Multilateralism // Globalisation, Democratisation and Multilateralism / S. Gill (ed.). Basingstoke: Macmillan.

Hajnal P.I. (2014) The G20. Evolution, Interrelationships, Documentation. Routledge.

Hardy M. (1969) The Diplomatic Activities of International Organizations: The United Nations and the European Communities Contrasted // Revue Beige de Droit International. No. 2.

Inayatullah S. (2010) Deconstructing and Reconstructing the Global Financial Crisis // Experiments with peace: celebrating peace on Johan Galtung's 80th birthday / J. Johansen, J.Y. Jones (eds). Cape Town: Pambazuka Press.

Keohane R., Nye Jr.J. (2011) Power and Independence. World Politics in Transition. Fourth Edition. N.Y.: Longman.

Kirton J., Larionova M., Savona P. (eds) (2010) Making Global Economic Governance Effective: Hard and Soft Law Institutions in a Crowded World. Farnham, U.K.: Ashgate.

Kirton J. (2011) The Group of Twenty // Handbook of Transnational Governance Innovation / T. Hale, D. Held (eds). L.: Polity Press.

Kirton J. (2013) G20 Governance for a Globalized World. Farnham: Ashgate.

Lesage D. (2007) Is the World Imaginable Without the G8? // Internationale Politik und Gesellschaft. Vol. 4. Режим доступа: http://www.fes.de/ipg/2007/4/09_Lesage_US.pdf (дата обращения: 10.02.2017).

Martin P. (2011) The G20: From Global Crisis Responder to Global Steering Committee // Global Leadership in Transition: Making the G20 More Effective and Responsive / C.I. Bradford, W.H. Lim (eds). Washington, DC: Brookings Institution Press with Korean Development Institute.

Myung-bak L. (2010) Seoul G20 Summit: Priorities and Challenges. Davos, Switzerland, 28 January.

OECD (2016) Member Countries’ Budget Contributions, Budget. Режим доступа: www.oecd.org/about/ budget/member-countries-budget-contributions.htm (дата обращения: 10.02.2017).

Pal L.A. (2012) Frontiers of Governance: The OECD and Global Public Management Reform. Basingstoke: Palgrave Macmillan.

Ramos G.I. (2011) The OECD in the G20: A Natural Partner in Global Governance // The George Washington International Law Review. Vol. 43. No. 2. P. 325-343.

Rewizorski M. (2014) From Washington to St. Petersburg. Development of the G20 as a New Centre of Global Governance. Berlin: Logos Verlag.

Rosenau J., Czempiel E.-O. (eds) (1992) Governance without Government. Order and Change in World Politics. Cambridge: Cambridge University Press.

Rosenau J.N. (1995) Governance in the Twenty-first Century // Global Governance. Vol. 1. No. 1.

Schumpeter J. (1942) Capitalism, Socialism, and Democracy. N. Y.: Harper \& Bros. 
Sinclair J. (2009) The New Global Governance: Time for a Great Leap Forward // Options Poliques, Novembere.

Slaughter S. (2015) Building G20 Outreach: The Role of Transnational Policy Networks in Sustaining Effective and Legitimate Summitry // Global Summitry. Vol. 1. Iss. 2. P. 171-186.

Stoker G. (1998) Governance as Theory: Five Propositions // International Social Science Journal. Vol. 50. Iss. 155.

Wade R., Vestergaard J. (2012) The G20 has Served its Purpose and Should be Replaced // Journal of Globalization and Development. Vol. 2. No. 2. 